

The impact of COVID-19 on the mechanisms and methods of conducting the microteaching course: The case of sophomore students at October 6 University

Assoc. Prof. Dr. Marghany Mahmoud Marghany

Head

Department of Languages \& Translation

Higher Institute for Specific Studies, HaramAbstract

Dr. Mai El-Said

Department of Curricula \& Instruction

October 6 University 



\title{
The impact of COVID-19 on the mechanisms and methods of conducting the microteaching course: The case of sophomore students at October 6 University
}

\author{
Assoc. Prof. Dr. Marghany Mahmoud Marghany \\ Head \\ Department of Languages \& Translation \\ Higher Institute for Specific Studies, Haram \\ Dr. Mai Ahmed El-Said \\ Department of Curricula \& InstructionOctober 6 University
}

\begin{abstract}
The present study investigated the mechanisms and methods which the October 6 University sophomores prefer for conducting the course of microteaching during the COVID-19 pandemic. It analyzed whether the participants prefer face-to-face lectures or online lectures in studying the microteaching course. The study also discussed the types of online lectures which the participants prefer and accounted for their preference. The study evaluated the participants' views on the methods in which the microteaching lectures can be conducted. Whether the microteaching lectures should separate or combine theory and practice under the circumstances of COVID-19. The study adopted a semi-quasi research design as it surveyed the perception of some sophomore students, at the faculty of Education, October 6 University, about the mechanisms and methods of conducting the practically and theoretically based course of microteaching. Thus, the study adopted a mixed quantitative and qualitative method. Quantification of collected data appears in using descriptive statistics to analyze the participants' responses to the questionnaire and the semi-structured interview based tasks. Meanwhile the analysis of qualitative data is embodied in the description of such responses. The findings indicated that the participants preferred the online lectures to the face-to-face lectures because of the impact of the global COVID-19 crisis. Out of the different online programmes, they signaled out the Microsoft teams programme to have microteaching lecture. As for the methods of conducting the microteaching course, they opted for the theoretically-practically combined sessions. The current study introduced implications for the teaching of microteaching course in the Egyptian context during the COVID-19 pandemic.
\end{abstract}

Keywords: COVID-19- microteaching course- mechanisms- methodsface-to-face- lectures- online lectures- perception- Egyptian EFL context- 
The impact of COVID-19 on the mechanisms and methods of conducting the microteaching course: The case of sophomore students at October 6 University

تأثثير كوفيد-9 1 على آليات و طرق تدريس مادة التدريس المصغر: دراسة حالة لطلاب الفرقة الثانية بجامعة ج أكتوبر

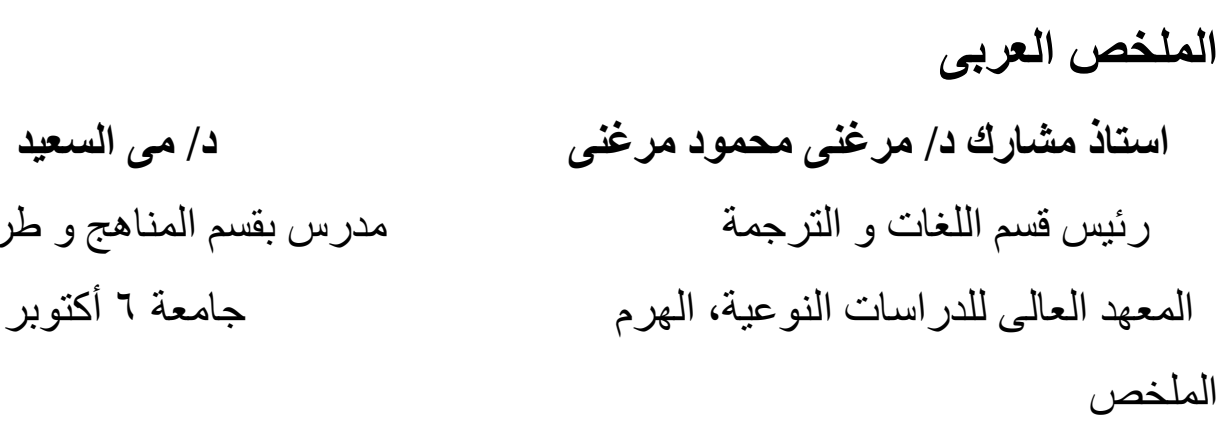

بحثت الدر اسة الحالية آليات و طرق التدريس التى يفضلها طلاب الفرقة الثانية بجامعة 7 أكتوبر

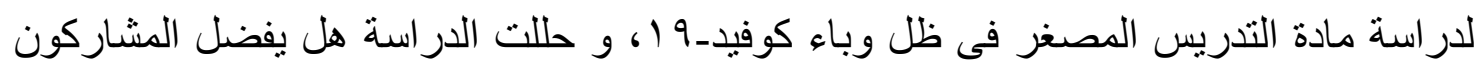
المحاضر ات وجها لوجه أو المحاضر ات الأونلاين قى در استهم لمادة التدريس المصغر ، و و ناقتنت

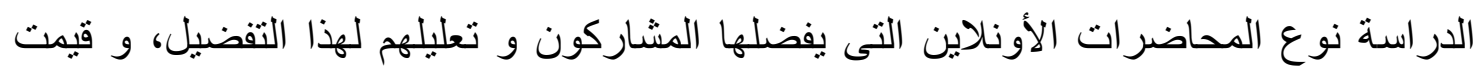

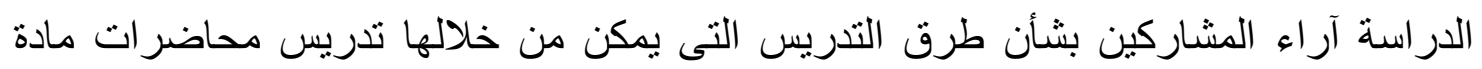

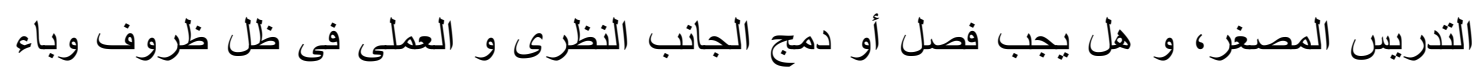
الكوفيد-9 1، و أعتمدت الدراسة على التصميم البحثى الثبه تجريبى حيث أنها أستطلعت آراء

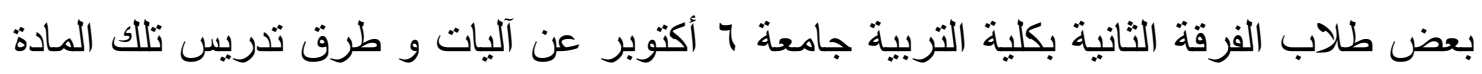

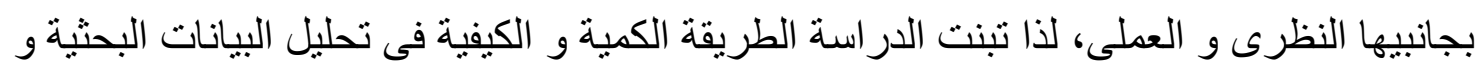
تمثل التحليل الكمى فى أستخدام الإحصاء الوصفى فى تحليل إستجابات المشاركين على الأستبيان

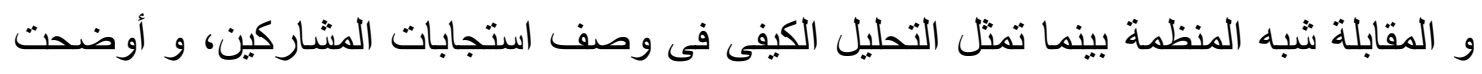







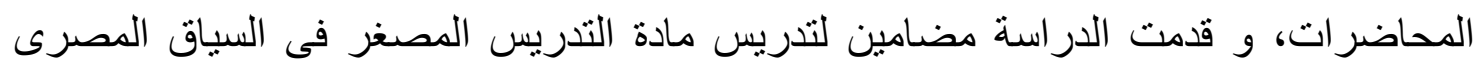
خلال وباء كوفيد-19 ـ الكلمات المفتاحية: مادة التدريس المصغر - آلياتـ طرق تدريس- المحاضرات وجها لوجهـ

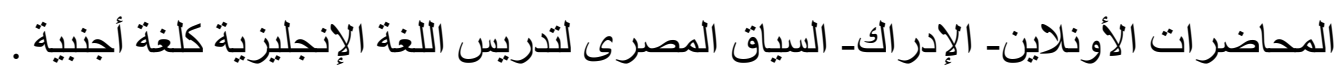




\section{Introduction}

According to the UNESCO report of 2020, several universities and higher learning institutions all over the world have shut down and turned to online teaching courses in order to encounter the outbreak of COVID19. Likewise, the situation in Egypt was not better than other countries as the closure of universities and higher learning institution officially started in mid-March 2019; almost four weeks since the beginning of second semester in February 2019. That is, the Egyptian EFL students were taught via face-to-face lectures for almost a few weeks, while they received online lectures for the rest of the second term of the academic year 2109-2020. Like all other undergraduates in the world at large, the Egyptian EFL students had to stay at home while receiving online education. Some courses, like that of microteaching, have a special orientation as they combine both theoretical and practical aspects. This poses a question about the mechanisms and methods of the online teaching of the theory and practice based course of microteaching at the time of COVID-19. To the authors' knowledge there are no other documented studies that investigate how the microteaching course was conducted under the condition of COVID-19 in the Egyptian EFL context. Therefore, it was felt necessary to measure how faculty of education students perceived the mechanisms and methods of teaching that course through face-to-face lectures or via online means of teaching.

\section{Statement of the Problem}

The present study investigated the mechanisms and methods which the October 6 University sophomores prefer for conducting the course of microteaching. It analyzed whether the participants prefer face-to-face lectures or online lectures in studying the microteaching course. The study also discussed the types of online lectures which the participants prefer and accounted for their preference. The study evaluated the participants' views on the methods in which the microteaching lectures can be conducted. Whether the microteaching lectures should separate or combine theory and practice under the circumstances of COVID-19.

\section{Questions}

The present study attempted to answer the following questions:

1. Which teaching mechanism do participants think is better for conducting the micro-teaching sessions, face-to-face lectures or online lectures? Why?

2. What type of online lectures do they prefer?

3. Which teaching method do participants think is better for conducting the micro-teaching sessions, separated sessions of theory and practice or combined sessions of theory and practice? Why? 
The impact of COVID-19 on the mechanisms and methods of conducting the microteaching course: The case of sophomore students at October 6 University

\section{Aims}

The study aimed to:

1. Measure the participants' perception about the best mechanisms and methods of conducting the microteaching lectures during the time of COVID-19.

2. Determine their views on conducting the microteaching course through face-to-face lectures and online lectures.

3. State the type of online lectures which they prefer.

4. State the method of conducting the microteaching course which participants prefer; whether separated or combined sessions of theory and practice.

\section{Significance of the Study}

The significance of the current study is attributed to the fact that it helps to document the process of teaching the microteaching course at the time of Corona virus. The study is also significant because it is consistent with the directives of His Excellency President of Egypt to encounter the impacts of COVID-19 on the continuation of teaching at the Egyptian Universities and Higher Learning institutions. It also supports the presidential endeavours to establish online teaching platforms in Egypt and the need of the Ministry of Higher Education to measure the perception of some Egyptian EFL students about the online teaching platforms in Egypt. The study is significant because it might be an unprecedented TEFL study in the Egyptian context. It is of a special significance to the faculty of Education, October 6 University because it discussed the mechanisms and methods of teaching a practically and theoretically mixed course like microteaching under the developments of a globally effective pandemic, i.e. COVID-19.

\section{Delimitations}

The study is delimited to the Faculty of Education, October 6 University in the sense that its findings are expected to guide the process of teaching microteaching to its sophomore students under the conditions of COVID-19. However, these findings can generally be useful to the teaching of this course at other faculties of Education which encounter similar circumstances under COVID-19.

\section{Literature Review}

This section reviewed studies pertinent to the transition to online courses instead of the face-to-face since the closure of higher learning 
institutions due to the outbreak of COVID-19. To economize on the space, the following four studies were discussed below.

Bao (2020) discussed the online education at the Chinese Peking University in facing the serious consequences of COVID-19. In this regard, Bao introduced six strategies of instruction pertinent to online teaching experiences at the time of Corona virus breakout. In this regard, Bao concluded that online education is highly affected by certain principles. First, the relevance between the online education design and the students' ability of learning. That is, the online education design should pay attention to how students can learn effectively. For this purpose, Boa suggested that the faculty can divide students in small groups to give them an opportunity of interacting with the online teaching instructor. Second, how the instructors are effective in conveying the online education information. That is, in traditional face-to-face classes, the instructors' facial expressions and body language can help students understand the delivered knowledge. However, in online classes such privileges could be restricted. Thus, instructors should have more reliance on their voice which should be as slow as possible to give students a chance to understand the main points of knowledge. Third, the faculty and teaching assistants' roles are in providing adequate support to students. That is, teaching assistants should be always available to meet the technical requirements of online teaching which face-to-face classes often do not require. Fourth, the improvement of students' learning ability. That is, instructors should aim to strengthen the active learning ability of their students. That could be realized through assignments and reading requirements. Fifth, emergency plans to handle unexpected things of the online teaching platforms. That is, universities should establish highquality platforms for online education in order to efficiently deliver online lectures to their students. Sixth, the online teaching should not ignore the possibility of students' inadequate participation. For this end, instructors can require students prior to the online class to submit a report on the topic of the intended class.

Garris and Fleck (2020) examined the evaluation of four hundred and eighty two undergraduates, enrolled in American higher education, of online courses during the crisis of COVID-19 pandemic. The participants comprised Native American, Asian, White, Black and Latin students. The participants had no previous experience in attending inline courses. They were studying a face-to-face course before the transition into online courses in the spring of 2020. They were selected from different American Universities and colleges and were surveyed online. Garris and Fleck (2020) found that generally the American undergraduates had negative evaluation of online courses. The American participants accounted their 
negative evaluation on the basis of lacking intercultural interaction during the online courses. They were not also as interested as in attending face-toface courses because the courses were less enjoyable as compared to faceto-face courses. They became less engaged in the online courses; they exerted less time and energy in demonstrating their learning skills and less meaningfully interactive with their colleagues. Garris and Fleck (2020) emphasized that participants' views were highly affected by their computer anxiety and self-efficacy in using technology to meet the requirements of all online courses. The participants' evaluation of online courses was also affected by the psychological disorders which many American had suffered from due to the reduced socialization following the COVID-19 pandemic.

Besser, Flett, and Zeigler-Hill (2020) investigated how 1.217 students enrolled in five higher learning institutions in Israel adapted to the online courses with the advent of COVID-19 pandemic. Data were collected via online questionnaire on adaptability. The participants were asked to report on their adaptability to online courses. The participants pointed out the challenges which they encountered at the early stages of the online courses. These challenges include high level of negative mood, less motivation compared to traditional courses and loneliness. However, the researchers found that participants positively adapted to the transition from face-to-face courses to online courses. Their adaptability was attributed to their personal traits that helped them interact with online learning. As the participants realized the uncertainty that accompanied the Coronavirus, they managed to adjust to the new changes that affected the ways they attended courses. Their adaptability was also significantly related to their learning experiences. The participants' ability to adapt to online courses was also attributed to their general feeling of belonging to the college and the inevitability of having online courses instead of faceto-face course due to the COVID-19 global crisis.

Dhawan (2020) examined how COVID-19 challenged the education system in India including schools, colleges and universities which had been relying on the traditional ways of learning before the outbreak of that pandemic. Dhawan discussed the privileges, foibles, opportunities and challenges which online teaching poses on the process of learning and teaching during this global crisis. As for privileges, online teaching provides flexibility of time for students to listen to the recorded online lectures over and over again. In online courses, instructors design their teaching materials to cater for the needs of their students. Online teaching provides instructors with various audio, visual, and textual tools to 
facilitate communication with students. As for problems and challenges, Dhawan summarized problems related to online teaching in a number of issues including the login difficulty errors of downloading and uploading learning materials, audio and visual problems. Online teaching may affect students' participation and interaction and reduce the effectiveness of teaching as students do not have enough time to practice what they are taught. As for conclusion, Dhawan recommended online teaching as the only successful solution to meet the challenges imposed on pursuing the process of learning and teaching worldwide under the unforeseeable conditions of COVID-19 pandemic.

\section{Methodology}

\section{Research Design}

The study adopted a semi-quasi research design as it surveyed the perception of some sophomore students, at the faculty of Education, October 6 University, about the mechanisms and methods of conducting the practically and theoretically based course of microteaching. As such, the study adopted a mixed quantitative and qualitative method. Quantification of collected data appears in using descriptive statistics to analyze the participants' responses to the questionnaire and the semistructured interview based tasks. Meanwhile data quantification is embodied in the description of such responses (Leedy, and Ormrod, 2013, Johnson and Christensen, 2015 and O'Neill, 2016).

\section{Participants}

Data were collected at the beginning of the first term of the academic year 2020-2021. One hundred third year students at the Department of English, Faculty of Education, October 6 University were randomly selected to participate in the present study. They were selected because they were sophomore students at the breakout of COVID-19 and its subsequent closure of universities in mid-March 2020. The selected students experienced how the microteaching course was taught at face-toface lectures at the faculty of Education since the beginning of second term in February 2020. They also experienced how that course was taught online since the closure in mid-March 2020 till the end of the second term.

\section{Data Collection}

Data were collected through two instruments, namely a questionnaire-based task (Cohen, Manion, and Norrison, 2007, Christensen, Johnson, and Turner, 2014, and Arthur and Waring, 2017) and a semi-structured interview-based task (Pramodini, and Anu Sophia, 2012, Hartawati, Sudirman, and Adnayni, 2018, and Tight, 2018 ). As for the questionnaire, it is divided into two parts. Part 1 consists of 32 items (1-32) covering the mechanisms of conducting micro-teaching sessions of English. Part 2 includes 32 items (33-64) handling the methods of 
conducting the micro-teaching sessions of English. The teaching tools include: (1) face-to-face lecturers, and (2) online lectures. Meanwhile, the teaching methods refer to: (1) separated sessions of theory and practice, and (2) combined sessions of theory and practice.

\section{Procedure}

As for the questionnaire, participants were asked to respond to the questionnaire items on the best mechanisms and methods of conducting the micro-teaching sessions under the conditions of COVID-19. They were asked to put a tick $\sqrt{ }$ before the response that represents their opinion. The five potential responses are formed in the Likert scale: $S D=$ Strongly Disagree, $\mathrm{D}=$ Disagree, $\mathrm{NS}=$ Not Sure, $\mathrm{SA}=$ Strongly Agree, and $\mathrm{A}=$ Agree.

As for the interview based task, participants were required to answer in detail questions on the best mechanism and methods of conducting the micro-teaching sessions under the conditions of COVID-19 and fully account for their answer. On the completion of both tasks, participants were instructed to email the files to one of the coauthors and submit hard copies of the files to her as well at her office at the faculty of Education, October 6 University.

A pilot study was conducted to assess the reliability of the questionnaire-based task and the semi-structured interview. For this purpose, twenty students participated in the pilot study. The Cronbach Alpha for the questionnaire-based task was .94 while it was .92 for the semi-structured interview suggesting high reliability for both instruments of data collection (Williams, 2015, and Martin and Jamieson-Proctor, 2020).

\section{Data Analysis}

\section{A Questionnaire-based Task}

As for part 1: mechanisms of conducting the microteaching sessions of English, Table 1 shows (30\%) of participants strongly agreed that faceto-face lectures the best to help them describe their overall performance compared to $(54 \%)$ of participants strongly agreed that online lectures are the best in describing their performance. For interaction with students, (22.8\%) strongly agreed that face-to-face lecture is the best while (54.8\%) of participants strongly agreed that online lectures are the best to fulfill interaction with students. For organizing the group work with students, the online lectures (44.9\%) surpassed face-to-face lectures (21.4\%). For handling the student's evaluation sheet, online lectures had higher percentage $(47.7 \%)$ compared to that of face-to-face lectures $(21.1 \%)$. However for writing the answers on the board, (38.8\%) of participants 
preferred face-to-face lectures compared to (12.6\%) of them preferring the online lectures. For sticking to a lesson timing schedule, online lectures (27.6\%) surpassed face-to-face lectures (19.9\%). For determining the successful parts of their lesson, a less percentage of participants $(16.1 \%)$ strongly agreed to face-to-face lectures compared to $(38.3 \%)$ of them recommended the online lectures. Similarly, (31.8\%) strongly agreed that online lectures are the best to determine how successful was the lesson compared to $(14.1 \%)$ for the face-to-face lectures. For describing any parts of their lesson that they were unhappy with, (50.7\%) of participants preferred the online lectures compared to (15.4\%) who preferred the face-to-face lectures. Likewise (50.4\%) of participants strongly agreed that online lectures help them think of lesson improvement compared (28.2\%) for face-to-face lectures. For the purpose of evaluating presentation of the lesson materials, online lectures had higher percentage (37.9\%) compared to that of face-to-face-lectures (17.1\%). For items 23,24,25, and 26, online lectures also had higher percentages (38\%) and (51\%) respectively compared to face-to-face-lectures (20\%) and (16.9\%). In addition, (48.2\%) of participants strongly agreed that Face-to-face lectures help pre-service teachers to learn from observing their peers compared to $(18.2 \%)$ for online lectures. For accurate planning of lessons and preparation of lesson, $(42.3 \%)$ and (39.8\%) strongly agreed can fulfill the task compared to $(25.5 \%)$ and $(26.5 \%)$ for face-to-face lectures successively.

As for the methods of conducting the micro-teaching sessions of English described in Part 2, Table 1 indicates that participants were in favour of combining theory and practice when attending microteaching sessions rather than separating them. This was evident in the higher percentage of their strongly agree responses of the combination between theory and practice sessions items included in the second part of the questionnaire-based task.

\section{Table 1: Participants' responses to the questionnaire-based-task}

\begin{tabular}{|l|l|l|l|l|l|l|l|l|l|l|l|}
\hline No. & $\begin{array}{l}\text { Part 1: Items } \\
\text { of tools }\end{array}$ & $\begin{array}{l}\text { SD } \\
5 \%\end{array}$ & $\begin{array}{l}\mathrm{D} \\
4 \%\end{array}$ & $\begin{array}{l}\text { Not } \\
\text { Sure } \\
3\end{array}$ & $\begin{array}{l}\text { SA } \\
2 \\
\%\end{array}$ & A 1 & Mean & $\begin{array}{l}\text { St. } \\
\text { Dev. }\end{array}$ & Min & Max & variance \\
\hline $\mathbf{1}$ & $\begin{array}{l}\text { I think face-to- } \\
\text { face lectures } \\
\text { are the best to } \\
\text { help me } \\
\text { describe my } \\
\text { overall } \\
\text { performance }\end{array}$ & 13 & 22 & 11 & 30 & 24 & 2.70 & 1.38 & 1 & 5 & 1.92 \\
\hline $\mathbf{2}$ & $\begin{array}{l}\text { It is helpful to } \\
\text { describe my } \\
\text { overall } \\
\text { performance } \\
\text { through online }\end{array}$ & 4 & 12 & 8 & 54 & 22 & 2.22 & 1.05 & 1 & 5 & 1.10 \\
\hline
\end{tabular}


The impact of COVID-19 on the mechanisms and methods of conducting the microteaching course: The case of sophomore students at October 6 University

\begin{tabular}{|c|c|c|c|c|c|c|c|c|c|c|c|}
\hline No. & $\begin{array}{l}\text { Part 1: Items } \\
\text { of tools }\end{array}$ & $\begin{array}{l}\text { SD } \\
5 \%\end{array}$ & $\begin{array}{l}\mathrm{D} \\
4 \%\end{array}$ & $\begin{array}{l}\text { Not } \\
\text { Sure } \\
3\end{array}$ & $\begin{array}{l}\text { SA } \\
2 \\
\%\end{array}$ & A 1 & Mean & $\begin{array}{l}\text { St. } \\
\text { Dev. }\end{array}$ & Min & Max & variance \\
\hline & lectures. & & & & & & & & & & \\
\hline 3 & $\begin{array}{l}\text { I think face-to- } \\
\text { face lectures } \\
\text { are the best to } \\
\text { teach me how } \\
\text { to interact with } \\
\text { my students }\end{array}$ & 15.5 & 19.5 & 6.5 & 22.8 & 17.1 & 2.92 & 1.64 & 1 & 5 & 2.13 \\
\hline 4 & $\begin{array}{l}\text { It is helpful to } \\
\text { learn how to } \\
\text { interact with } \\
\text { my students } \\
\text { through online } \\
\text { lectures }\end{array}$ & 1.6 & 4.9 & 4.9 & 54.8 & 33.8 & 2.11 & .85 & 1 & 5 & .73 \\
\hline 5 & $\begin{array}{l}\text { I think face-to- } \\
\text { face lectures } \\
\text { are the best to } \\
\text { teach me how } \\
\text { to organize the } \\
\text { group work } \\
\text { with your } \\
\text { students }\end{array}$ & 19.4 & 38.8 & 4.1 & 21.4 & 16.3 & 2.97 & 1.41 & 1 & 5 & 1.98 \\
\hline 6 & $\begin{array}{l}\text { It is helpful to } \\
\text { learn how to } \\
\text { organize the } \\
\text { group work } \\
\text { with your } \\
\text { students } \\
\text { through online } \\
\text { lectures }\end{array}$ & 6.5 & 6.5 & 4.2 & 44.9 & 37.9 & 2.15 & 1.17 & 1 & 5 & 1.38 \\
\hline 7 & $\begin{array}{l}\text { I think face-to- } \\
\text { face lectures } \\
\text { are the best to } \\
\text { teach me how } \\
\text { to handle the } \\
\text { student's } \\
\text { evaluation } \\
\text { sheet }\end{array}$ & 38.9 & 20.9 & 8.3 & 22.1 & 9.8 & 3.34 & 1.35 & 1 & 5 & 1.82 \\
\hline 8 & $\begin{array}{l}\text { It is helpful to } \\
\text { learn how to } \\
\text { handle the } \\
\text { student's } \\
\text { evaluation } \\
\text { sheet through } \\
\text { online lectures }\end{array}$ & 17.5 & 8.2 & 2.2 & 47.7 & 24.4 & 2.26 & 1.29 & 1 & 5 & 1.66 \\
\hline 9 & $\begin{array}{l}\text { I think face-to- } \\
\text { face lectures } \\
\text { are the best to } \\
\text { help pre- } \\
\text { service } \\
\text { teachers to } \\
\text { write the } \\
\text { answers on } \\
\text { the board }\end{array}$ & 13.8 & 23.6 & - & 38.8 & 23.8 & 2.90 & 1.44 & 1 & 5 & 2.09 \\
\hline
\end{tabular}




\section{Dr. Marghany Mahmoud Marghany Dr. Mai Ahmed El-Said}

\begin{tabular}{|c|c|c|c|c|c|c|c|c|c|c|c|}
\hline No. & $\begin{array}{l}\text { Part 1: Items } \\
\text { of tools }\end{array}$ & $\begin{array}{l}\text { SD } \\
5 \%\end{array}$ & $\begin{array}{l}\mathrm{D} \\
4 \%\end{array}$ & $\begin{array}{l}\text { Not } \\
\text { Sure } \\
3\end{array}$ & $\begin{array}{l}\text { SA } \\
2 \\
\%\end{array}$ & A 1 & Mean & $\begin{array}{l}\text { St. } \\
\text { Dev. }\end{array}$ & Min & $\operatorname{Max}$ & variance \\
\hline & $\begin{array}{l}\text { with the } \\
\text { rest of the } \\
\text { class } \\
\text { feeding } \\
\text { them the } \\
\text { information } \\
\text { and } \\
\text { corrections } \\
\text { if they went } \\
\text { wrong. }\end{array}$ & & & & & & & & & & \\
\hline 10 & $\begin{array}{l}\text { Online lectures } \\
\text { can help pre- } \\
\text { service } \\
\text { teachers to } \\
\text { write the } \\
\text { answers on } \\
\text { the board } \\
\text { with the } \\
\text { rest of the } \\
\text { class } \\
\text { feeding } \\
\text { them the } \\
\text { information } \\
\text { and } \\
\text { corrections } \\
\text { if they went } \\
\text { wrong. }\end{array}$ & 29.5 & 35.9 & 11.4 & 12.6 & 10.6 & 3.74 & 1.08 & 1 & 5 & 1.16 \\
\hline 11 & $\begin{array}{l}\text { I think face-to- } \\
\text { face lectures } \\
\text { are the best to } \\
\text { help pre- } \\
\text { service } \\
\text { teachers to } \\
\text { stick to a } \\
\text { lesson } \\
\text { timing } \\
\text { schedule }\end{array}$ & 27.8 & 26.8 & - & 19.9 & 25.5 & 3.05 & 1.53 & 1 & 5 & 2.37 \\
\hline 12 & $\begin{array}{l}\text { Online lectures } \\
\text { can help pre- } \\
\text { service } \\
\text { teachers to } \\
\text { stick to a } \\
\text { lesson } \\
\text { timing } \\
\text { schedule }\end{array}$ & 22.2 & 22.0 & 7.3 & 27.6 & 20.9 & 3.45 & 1.40 & 1 & 5 & 1.98 \\
\hline 13 & $\begin{array}{l}\text { I think face-to- } \\
\text { face lectures } \\
\text { are the best to } \\
\text { help pre- } \\
\text { service } \\
\text { teachers to } \\
\text { determine the } \\
\text { successful }\end{array}$ & 24.4 & 30.3 & - & 16.1 & 29.2 & 2.71 & 1.60 & 1 & 5 & 2.59 \\
\hline
\end{tabular}


The impact of COVID-19 on the mechanisms and methods of conducting the microteaching course: The case of sophomore students at October 6 University

\begin{tabular}{|c|c|c|c|c|c|c|c|c|c|c|c|}
\hline No. & $\begin{array}{l}\text { Part 1: Items } \\
\text { of tools }\end{array}$ & $\begin{array}{l}\text { SD } \\
5 \%\end{array}$ & $\begin{array}{l}\mathrm{D} \\
4 \%\end{array}$ & $\begin{array}{l}\text { Not } \\
\text { Sure } \\
3\end{array}$ & $\begin{array}{l}\text { SA } \\
2 \\
\%\end{array}$ & A 1 & Mean & $\begin{array}{l}\text { St. } \\
\text { Dev. }\end{array}$ & Min & Max & variance \\
\hline & $\begin{array}{l}\text { parts of their } \\
\text { lesson }\end{array}$ & & & & & & & & & & \\
\hline 14 & $\begin{array}{l}\text { Online lectures } \\
\text { can help pre- } \\
\text { service } \\
\text { teachers to } \\
\text { determine the } \\
\text { successful } \\
\text { parts of their } \\
\text { lesson }\end{array}$ & 15.1 & 10.2 & - & 38.3 & 36.4 & 2.32 & 1.23 & 1 & 5 & 1.51 \\
\hline 15 & $\begin{array}{l}\text { I think face-to- } \\
\text { face lectures } \\
\text { are the best to } \\
\text { help pre- } \\
\text { service } \\
\text { teachers to } \\
\text { determine how } \\
\text { successful was } \\
\text { the lesson to } \\
\text { their students }\end{array}$ & 25.4 & 44.3 & - & 14.1 & 16.2 & 3.26 & 1.44 & 1 & 5 & 2.09 \\
\hline 16 & $\begin{array}{l}\text { Online lectures } \\
\text { can help pre- } \\
\text { service } \\
\text { teachers to } \\
\text { determine how } \\
\text { successful was } \\
\text { the lesson to } \\
\text { their students }\end{array}$ & 17.2 & 10.6 & 4.1 & 31.8 & 36.3 & 2.65 & 1.57 & 1 & 5 & 2.47 \\
\hline 17 & $\begin{array}{l}\text { I think face-to- } \\
\text { face lectures } \\
\text { are the best to } \\
\text { help pre- } \\
\text { service } \\
\text { teachers to } \\
\text { describe any } \\
\text { parts of their } \\
\text { lesson that } \\
\text { they were } \\
\text { unhappy with } \\
\text { and indicate } \\
\text { what they } \\
\text { would do in a } \\
\text { future similar } \\
\text { class. }\end{array}$ & 22.4 & 45.8 & - & 15.4 & 16.4 & 3.52 & 1.39 & 1 & 5 & 1.94 \\
\hline 18 & $\begin{array}{l}\text { Online lectures } \\
\text { can help pre- } \\
\text { service } \\
\text { teachers } \\
\text { describe } \\
\text { any parts of } \\
\text { their lesson } \\
\text { that they were } \\
\text { unhappy with }\end{array}$ & 8.3 & 6.5 & - & 50.7 & 34.5 & 2.18 & 1.26 & 1 & 5 & 1.60 \\
\hline
\end{tabular}




\section{Dr. Marghany Mahmoud Marghany Dr. Mai Ahmed El-Said}

\begin{tabular}{|c|c|c|c|c|c|c|c|c|c|c|c|}
\hline No. & $\begin{array}{l}\text { Part 1: Items } \\
\text { of tools }\end{array}$ & $\begin{array}{l}\text { SD } \\
5 \%\end{array}$ & $\begin{array}{l}\mathrm{D} \\
4 \%\end{array}$ & $\begin{array}{l}\text { Not } \\
\text { Sure } \\
3\end{array}$ & $\begin{array}{l}\text { SA } \\
2 \\
\%\end{array}$ & A 1 & Mean & $\begin{array}{l}\text { St. } \\
\text { Dev. }\end{array}$ & Min & $\operatorname{Max}$ & variance \\
\hline & $\begin{array}{l}\text { and indicate } \\
\text { what they } \\
\text { would do in a } \\
\text { future similar } \\
\text { class. }\end{array}$ & & & & & & & & & & \\
\hline 19 & $\begin{array}{l}\text { I believe face- } \\
\text { to-face lectures } \\
\text { are the best to } \\
\text { help pre- } \\
\text { service } \\
\text { teachers to } \\
\text { think about the } \\
\text { lesson } \\
\text { improvement }\end{array}$ & 29.4 & 23.7 & - & 28.2 & 18.7 & 2.70 & 1.47 & 1 & 5 & 2.19 \\
\hline 20 & $\begin{array}{l}\text { Online lectures } \\
\text { can help pre- } \\
\text { service } \\
\text { teachers to } \\
\text { think about the } \\
\text { lesson } \\
\text { improvement }\end{array}$ & 15.6 & 17.7 & - & 50.4 & 16.3 & 2.25 & 1.14 & 1 & 5 & 1.32 \\
\hline 21 & $\begin{array}{l}\text { I think face-to- } \\
\text { face lectures } \\
\text { are the best to } \\
\text { help me } \\
\text { evaluate my } \\
\text { presentation of } \\
\text { the lesson } \\
\text { materials }\end{array}$ & 26.8 & 38.8 & - & 17.1 & 17.3 & 3.16 & 1.50 & 1 & 5 & 2.25 \\
\hline 22 & $\begin{array}{l}\text { Online lectures } \\
\text { can help pre- } \\
\text { service } \\
\text { teachers to } \\
\text { evaluate their } \\
\text { presentation of } \\
\text { the lesson } \\
\text { materials }\end{array}$ & 8.1 & 18.5 & - & 37.9 & 35.5 & 2.47 & 1.40 & 1 & 5 & 1.96 \\
\hline 23 & $\begin{array}{l}\text { I think face-to- } \\
\text { face lectures } \\
\text { are the best to } \\
\text { help me decide } \\
\text { whether I } \\
\text { varied the } \\
\text { instructional } \\
\text { materials } \\
\text { which I used. }\end{array}$ & 29.0 & 29.0 & - & 20.0 & 22.0 & 2.89 & 1.59 & 1 & 5 & 2.55 \\
\hline 24 & $\begin{array}{l}\text { Online lectures } \\
\text { can help pre- } \\
\text { service } \\
\text { teachers to } \\
\text { decide whether } \\
\text { they varied the } \\
\text { instructional } \\
\text { materials } \\
\text { which they }\end{array}$ & 16.2 & 17.1 & - & 38.0 & 28.7 & 2.78 & 1.51 & 1 & 5 & \\
\hline
\end{tabular}


The impact of COVID-19 on the mechanisms and methods of conducting the microteaching course: The case of sophomore students at October 6 University

\begin{tabular}{|c|c|c|c|c|c|c|c|c|c|c|c|}
\hline No. & $\begin{array}{l}\text { Part 1: Items } \\
\text { of tools }\end{array}$ & $\begin{array}{l}\text { SD } \\
5 \%\end{array}$ & $\begin{array}{l}\mathrm{D} \\
4 \%\end{array}$ & $\begin{array}{l}\text { Not } \\
\text { Sure } \\
3\end{array}$ & $\begin{array}{l}\text { SA } \\
2 \\
\%\end{array}$ & A 1 & Mean & $\begin{array}{l}\text { St. } \\
\text { Dev. }\end{array}$ & Min & Max & variance \\
\hline & used. & & & & & & & & & & \\
\hline 25 & $\begin{array}{l}\text { Face-to-face } \\
\text { lectures can } \\
\text { help reduce } \\
\text { pressure on } \\
\text { pre-service } \\
\text { teachers when } \\
\text { practicing their } \\
\text { micro-teaching } \\
\text { sessions }\end{array}$ & 27.7 & 39.7 & - & 16.9 & 15.7 & 3.58 & 1.25 & 1 & 5 & 1.57 \\
\hline 26 & $\begin{array}{l}\text { Online lectures } \\
\text { can help } \\
\text { reduce } \\
\text { pressure on } \\
\text { pre-service } \\
\text { teachers when } \\
\text { practicing their } \\
\text { micro-teaching } \\
\text { sessions }\end{array}$ & 9.8 & 9.8 & - & 51.0 & 29.4 & 2.36 & 1.29 & 1 & 5 & \\
\hline 27 & $\begin{array}{l}\text { Face-to-face } \\
\text { lectures can } \\
\text { help pre- } \\
\text { service } \\
\text { teachers to } \\
\text { learn from } \\
\text { observing their } \\
\text { peers. }\end{array}$ & 9.0 & 11.4 & - & 48.2 & 31.4 & 2.02 & .90 & 1 & 5 & .82 \\
\hline 28 & $\begin{array}{l}\text { Online lectures } \\
\text { can help pre- } \\
\text { service } \\
\text { teachers to } \\
\text { learn from } \\
\text { observing their } \\
\text { peers. }\end{array}$ & 37.0 & 28.5 & - & 18.2 & 16.3 & 3.18 & 1.52 & 1 & 5 & 2.31 \\
\hline 29 & $\begin{array}{l}\text { I think face-to- } \\
\text { face lectures } \\
\text { are the best to } \\
\text { help pre- } \\
\text { service } \\
\text { teachers in } \\
\text { their lesson } \\
\text { planning }\end{array}$ & 26.0 & 22.0 & - & 25.5 & 26.5 & 3.29 & 1.59 & 1 & 5 & 2.53 \\
\hline 30 & $\begin{array}{l}\text { Online lectures } \\
\text { can help pre- } \\
\text { service } \\
\text { teachers to } \\
\text { plan their } \\
\text { lessons } \\
\text { accurately }\end{array}$ & 16.4 & 18.6 & - & 42.3 & 22.7 & 2.64 & 1.31 & 1 & 5 & 1.72 \\
\hline 31 & $\begin{array}{l}\text { I think face-to- } \\
\text { face lectures } \\
\text { are the best to } \\
\text { help pre- }\end{array}$ & 22.9 & 31.7 & - & 26.5 & 18.9 & 3.15 & 1.34 & 1 & 5 & 1.80 \\
\hline
\end{tabular}




\section{Dr. Marghany Mahmoud Marghany}

Dr. Mai Ahmed El-Said

\begin{tabular}{|c|c|c|c|c|c|c|c|c|c|c|c|}
\hline No. & $\begin{array}{l}\text { Part 1: Items } \\
\text { of tools }\end{array}$ & $\begin{array}{l}\text { SD } \\
5 \%\end{array}$ & $\begin{array}{l}\mathrm{D} \\
4 \%\end{array}$ & $\begin{array}{l}\text { Not } \\
\text { Sure } \\
3\end{array}$ & $\begin{array}{l}\text { SA } \\
2 \\
\%\end{array}$ & A 1 & Mean & $\begin{array}{l}\text { St. } \\
\text { Dev. }\end{array}$ & Min & Max & variance \\
\hline & $\begin{array}{l}\text { service } \\
\text { teachers in } \\
\text { preparing their } \\
\text { lessons }\end{array}$ & & & & & & & & & & \\
\hline 32 & $\begin{array}{l}\text { Online lectures } \\
\text { can help pre- } \\
\text { service } \\
\text { teachers to } \\
\text { prepare their } \\
\text { lessons } \\
\text { accurately }\end{array}$ & 13.2 & 24.4 & - & 39.8 & 22.0 & 2.27 & 1.21 & 1 & 5 & 1.47 \\
\hline \multicolumn{12}{|c|}{ Part 2: Items of Methods } \\
\hline 33 & $\begin{array}{l}\text { Separation of } \\
\text { theory from } \\
\text { practice helps } \\
\text { me describe } \\
\text { my overall } \\
\text { performance }\end{array}$ & 22.0 & 35.3 & 15.4 & 9.2 & 18.1 & 3.88 & .92 & 1 & 5 & .85 \\
\hline 34 & $\begin{array}{l}\text { Combination } \\
\text { of theory and } \\
\text { practice is the } \\
\text { best method } \\
\text { that helps me } \\
\text { describe my } \\
\text { overall } \\
\text { performance }\end{array}$ & 15.0 & 17.8 & 8.9 & 36.7 & 21.6 & 2.40 & 1.23 & 1 & 5 & 1.53 \\
\hline 35 & $\begin{array}{l}\text { Separation of } \\
\text { theory from } \\
\text { practice helps } \\
\text { to learn how to } \\
\text { interact with } \\
\text { my students }\end{array}$ & 33.3 & 33.9 & 10.6 & 22.8 & 2.4 & 3.49 & 1.24 & 1 & 5 & 1.54 \\
\hline 36 & $\begin{array}{l}\text { Combination } \\
\text { of theory and } \\
\text { practice is the } \\
\text { best method } \\
\text { that teaches } \\
\text { how to interact } \\
\text { with my } \\
\text { students }\end{array}$ & 14.3 & 11.7 & 7.3 & 38.2 & 28.5 & 1.98 & 1.05 & 1 & 5 & 1.11 \\
\hline 37 & $\begin{array}{l}\text { Separation of } \\
\text { theory from } \\
\text { practice helps } \\
\text { me to learn } \\
\text { how to } \\
\text { organize the } \\
\text { group work } \\
\text { with my } \\
\text { students }\end{array}$ & 33.4 & 29.0 & 8.9 & 17.9 & 11.4 & 3.58 & 1.24 & 1 & 5 & 1.55 \\
\hline 38 & $\begin{array}{l}\text { Combination } \\
\text { of theory and } \\
\text { practice is the } \\
\text { best method } \\
\text { that helps me } \\
\text { to learn how to }\end{array}$ & 9.0 & 17.0 & 9.8 & 33.3 & 30.9 & 4.11 & .94 & 1 & 5 & .88 \\
\hline
\end{tabular}


The impact of COVID-19 on the mechanisms and methods of conducting the microteaching course: The case of sophomore students at October 6 University

\begin{tabular}{|c|c|c|c|c|c|c|c|c|c|c|c|}
\hline No. & $\begin{array}{l}\text { Part 1: Items } \\
\text { of tools }\end{array}$ & $\begin{array}{l}\text { SD } \\
5 \%\end{array}$ & $\begin{array}{l}\mathrm{D} \\
4 \%\end{array}$ & $\begin{array}{l}\text { Not } \\
\text { Sure } \\
3\end{array}$ & $\begin{array}{l}\text { SA } \\
2 \\
\%\end{array}$ & A 1 & Mean & $\begin{array}{l}\text { St. } \\
\text { Dev. }\end{array}$ & Min & Max & variance \\
\hline & $\begin{array}{l}\text { organize the } \\
\text { group work } \\
\text { with my } \\
\text { students }\end{array}$ & & & & & & & & & & \\
\hline 39 & $\begin{array}{l}\text { Separation of } \\
\text { theory from } \\
\text { practice helps } \\
\text { me how to } \\
\text { handle the } \\
\text { student's } \\
\text { evaluation } \\
\text { sheet }\end{array}$ & 22.0 & 33.3 & 7.3 & 19.7 & 18.7 & 3.72 & 1.10 & 1 & 5 & 1.21 \\
\hline 40 & $\begin{array}{l}\text { Combination } \\
\text { of theory and } \\
\text { practice is the } \\
\text { best method } \\
\text { that helps me } \\
\text { how to handle } \\
\text { the student's } \\
\text { evaluation } \\
\text { sheet }\end{array}$ & 19.7 & 18.7 & 7.9 & 24.4 & 29.3 & 2.21 & 1.16 & 1 & 5 & 1.35 \\
\hline 41 & $\begin{array}{l}\text { Separation of } \\
\text { theory from } \\
\text { practice helps } \\
\text { pre-service } \\
\text { teachers to } \\
\text { write the } \\
\text { answers on } \\
\text { the board } \\
\text { with the } \\
\text { rest of the } \\
\text { class } \\
\text { feeding } \\
\text { them the } \\
\text { information } \\
\text { and } \\
\text { corrections } \\
\text { if they went } \\
\text { wrong. }\end{array}$ & 32.0 & 39.0 & 14.0 & 17.0 & 9.0 & 3.46 & 1.25 & 1 & 5 & 1.56 \\
\hline 42 & $\begin{array}{l}\text { Combination } \\
\text { of theory and } \\
\text { practice is the } \\
\text { best method } \\
\text { that helps pre- } \\
\text { service } \\
\text { teachers to } \\
\text { write the } \\
\text { answers on } \\
\text { the board } \\
\text { with the } \\
\text { rest of the } \\
\text { class }\end{array}$ & 8.1 & 19.2 & 14.1 & 47.5 & 11.1 & 2.65 & 1.15 & 1 & 5 & 1.33 \\
\hline
\end{tabular}




\section{Dr. Marghany Mahmoud Marghany Dr. Mai Ahmed El-Said}

\begin{tabular}{|c|c|c|c|c|c|c|c|c|c|c|c|}
\hline No. & $\begin{array}{l}\text { Part 1: Items } \\
\text { of tools }\end{array}$ & $\begin{array}{l}\text { SD } \\
5 \%\end{array}$ & $\begin{array}{l}\mathrm{D} \\
4 \%\end{array}$ & $\begin{array}{l}\text { Not } \\
\text { Sure } \\
3\end{array}$ & $\begin{array}{l}\text { SA } \\
2 \\
\%\end{array}$ & A 1 & Mean & $\begin{array}{l}\text { St. } \\
\text { Dev. }\end{array}$ & Min & Max & variance \\
\hline & $\begin{array}{l}\text { feeding } \\
\text { them the } \\
\text { information } \\
\text { and } \\
\text { corrections } \\
\text { if they went } \\
\text { wrong. }\end{array}$ & & & & & & & & & & \\
\hline 43 & $\begin{array}{l}\text { Separation of } \\
\text { theory from } \\
\text { practice helps } \\
\text { pre-service } \\
\text { teachers to } \\
\text { stick to a } \\
\text { lesson } \\
\text { timing } \\
\text { schedule }\end{array}$ & 20.2 & 37.4 & 10.1 & 18.2 & 14.1 & 3.31 & 1.36 & 1 & 5 & 1.85 \\
\hline 44 & $\begin{array}{l}\text { Combination } \\
\text { of theory and } \\
\text { practice is the } \\
\text { best method } \\
\text { that helps pre- } \\
\text { service } \\
\text { teachers to } \\
\text { stick to a } \\
\text { lesson } \\
\text { timing } \\
\text { schedule }\end{array}$ & 9.0 & 24.0 & 11.0 & 39.0 & 17.0 & 2.69 & 1.26 & 1 & 5 & 1.59 \\
\hline 45 & $\begin{array}{l}\text { Separation of } \\
\text { theory from } \\
\text { practice helps } \\
\text { pre-service } \\
\text { teachers to } \\
\text { determine the } \\
\text { successful } \\
\text { parts of their } \\
\text { lesson }\end{array}$ & 23.0 & 39.0 & - & 29.0 & $\begin{array}{l}9.0 \\
\end{array}$ & 3.38 & 1.35 & 1 & 5 & 1.83 \\
\hline 46 & $\begin{array}{l}\text { Combination } \\
\text { of theory and } \\
\text { practice is the } \\
\text { best method } \\
\text { that helps pre- } \\
\text { service } \\
\text { teachers to } \\
\text { determine the } \\
\text { successful } \\
\text { parts of their } \\
\text { lesson }\end{array}$ & 19.0 & 17.0 & - & 40.0 & 27.0 & 2.97 & 1.42 & 1 & 5 & 2.00 \\
\hline 47 & $\begin{array}{l}\text { Separation of } \\
\text { theory from } \\
\text { practice helps } \\
\text { pre-service } \\
\text { teachers to } \\
\text { determine how } \\
\text { successful was }\end{array}$ & 22.2 & 25.3 & 14.1 & 33.3 & 5.1 & 3.26 & 1.27 & 1 & 5 & 1.62 \\
\hline
\end{tabular}


The impact of COVID-19 on the mechanisms and methods of conducting the microteaching course: The case of sophomore students at October 6 University

\begin{tabular}{|c|c|c|c|c|c|c|c|c|c|c|c|}
\hline No. & $\begin{array}{l}\text { Part 1: Items } \\
\text { of tools }\end{array}$ & $\begin{array}{l}\text { SD } \\
5 \%\end{array}$ & $\begin{array}{l}\mathrm{D} \\
4 \%\end{array}$ & $\begin{array}{l}\text { Not } \\
\text { Sure } \\
3\end{array}$ & $\begin{array}{l}\text { SA } \\
2 \\
\%\end{array}$ & A 1 & Mean & $\begin{array}{l}\text { St. } \\
\text { Dev. }\end{array}$ & Min & Max & variance \\
\hline & $\begin{array}{l}\text { the lesson to } \\
\text { their } \\
\text { students18 }\end{array}$ & & & & & & & & & & \\
\hline 48 & $\begin{array}{l}\text { Combination } \\
\text { of theory and } \\
\text { practice is the } \\
\text { best method } \\
\text { that helps pre- } \\
\text { service } \\
\text { teachers to } \\
\text { determine how } \\
\text { successful was } \\
\text { the lesson to } \\
\text { their students }\end{array}$ & 7.0 & 15.0 & 14.0 & 43.0 & 21.0 & 2.44 & 1.40 & 1 & 5 & 1.40 \\
\hline 49 & $\begin{array}{l}\text { Separation of } \\
\text { theory from } \\
\text { practice helps } \\
\text { pre-service } \\
\text { teachers to } \\
\text { describe } \\
\text { any parts of } \\
\text { their lesson } \\
\text { that they were } \\
\text { unhappy with } \\
\text { and indicate } \\
\text { what they } \\
\text { would do in a } \\
\text { future similar } \\
\text { class. }\end{array}$ & 21.0 & 36.0 & 12.0 & 18.0 & 13.0 & 3.34 & 1.34 & 1 & 5 & 1.80 \\
\hline 50 & $\begin{array}{l}\text { Combination } \\
\text { of theory and } \\
\text { practice is the } \\
\text { best method } \\
\text { that helps pre- } \\
\text { service } \\
\text { teachers to } \\
\text { describe } \\
\text { any parts of } \\
\text { their lesson } \\
\text { that they were } \\
\text { unhappy with } \\
\text { and indicate } \\
\text { what they } \\
\text { would do in a } \\
\text { future similar } \\
\text { class. }\end{array}$ & 13.0 & 15.0 & 9.0 & 45.0 & 18.0 & 2.60 & 1.30 & 1 & 5 & 1.69 \\
\hline 51 & $\begin{array}{l}\text { Separation of } \\
\text { theory from } \\
\text { practice helps } \\
\text { pre-service } \\
\text { teachers to } \\
\text { think about the } \\
\text { lesson }\end{array}$ & 36.0 & 30.0 & 9.0 & 16.0 & 9.0 & 3.68 & 1.34 & 1 & 5 & 1.81 \\
\hline
\end{tabular}




\section{Dr. Marghany Mahmoud Marghany Dr. Mai Ahmed El-Said}

\begin{tabular}{|c|c|c|c|c|c|c|c|c|c|c|c|}
\hline No. & $\begin{array}{l}\text { Part 1: Items } \\
\text { of tools }\end{array}$ & $\begin{array}{l}\text { SD } \\
5 \%\end{array}$ & $\begin{array}{l}\mathrm{D} \\
4 \%\end{array}$ & $\begin{array}{l}\text { Not } \\
\text { Sure } \\
3\end{array}$ & $\begin{array}{l}\text { SA } \\
2 \\
\%\end{array}$ & A 1 & Mean & $\begin{array}{l}\text { St. } \\
\text { Dev. }\end{array}$ & Min & $\operatorname{Max}$ & variance \\
\hline & improvement & & & & & & & & & & \\
\hline 52 & $\begin{array}{l}\text { Combination } \\
\text { of theory and } \\
\text { practice is the } \\
\text { best method } \\
\text { that helps pre- } \\
\text { service } \\
\text { teachers to } \\
\text { think about the } \\
\text { lesson } \\
\text { improvement }\end{array}$ & 9.0 & 18.0 & 9.0 & 46.0 & 18.0 & 2.45 & 1.23 & 1 & 5 & 1.52 \\
\hline 53 & $\begin{array}{l}\text { Separation of } \\
\text { theory from } \\
\text { practice helps } \\
\text { pre-service } \\
\text { teachers to } \\
\text { evaluate their } \\
\text { presentation of } \\
\text { the lesson } \\
\text { materials }\end{array}$ & 28.0 & 28.0 & 9.0 & 20.0 & 15.0 & 3.34 & 1.45 & 1 & 5 & 2.10 \\
\hline 54 & $\begin{array}{l}\text { Combination } \\
\text { of theory and } \\
\text { practice is the } \\
\text { best method } \\
\text { that helps pre- } \\
\text { service } \\
\text { teachers to } \\
\text { evaluate their } \\
\text { presentation of } \\
\text { the lesson } \\
\text { materials }\end{array}$ & 10.0 & 13.0 & 8.0 & 47.0 & 22.0 & 2.42 & 1.24 & 1 & 5 & 1.55 \\
\hline 55 & $\begin{array}{l}\text { Separation of } \\
\text { theory from } \\
\text { practice helps } \\
\text { pre-service } \\
\text { teachers to } \\
\text { decide whether } \\
\text { they varied the } \\
\text { instructional } \\
\text { materials } \\
\text { which they } \\
\text { used. }\end{array}$ & 33.0 & 23.0 & - & 22.0 & 22.0 & 3.23 & 1.61 & 1 & 5 & 2.62 \\
\hline 56 & $\begin{array}{l}\text { Combination } \\
\text { of theory and } \\
\text { practice is the } \\
\text { best method } \\
\text { that helps pre- } \\
\text { service } \\
\text { teachers to } \\
\text { decide whether } \\
\text { they varied the } \\
\text { instructional } \\
\text { materials } \\
\text { which they } \\
\text { used. }\end{array}$ & 13.0 & 24.0 & - & 41.0 & 22.0 & 2.65 & 1.39 & 1 & 5 & 1.94 \\
\hline
\end{tabular}


The impact of COVID-19 on the mechanisms and methods of conducting the microteaching course: The case of sophomore students at October 6 University

\begin{tabular}{|c|c|c|c|c|c|c|c|c|c|c|c|}
\hline No. & $\begin{array}{l}\text { Part 1: Items } \\
\text { of tools }\end{array}$ & $\begin{array}{l}\text { SD } \\
5 \%\end{array}$ & $\begin{array}{l}\mathrm{D} \\
4 \%\end{array}$ & $\begin{array}{l}\text { Not } \\
\text { Sure } \\
3\end{array}$ & $\begin{array}{l}\text { SA } \\
2 \\
\%\end{array}$ & A 1 & Mean & $\begin{array}{l}\text { St. } \\
\text { Dev. }\end{array}$ & Min & Max & variance \\
\hline 57 & $\begin{array}{l}\text { Separation of } \\
\text { theory from } \\
\text { practice can } \\
\text { help reduce } \\
\text { pressure on } \\
\text { pre-service } \\
\text { teachers when } \\
\text { practicing their } \\
\text { micro-teaching } \\
\text { sessions }\end{array}$ & 19.0 & 39.0 & - & 34.0 & 8.0 & 3.27 & 1.32 & 1 & 5 & 1.57 \\
\hline 58 & $\begin{array}{l}\text { Combination } \\
\text { of theory and } \\
\text { practice can } \\
\text { help reduce } \\
\text { pressure on } \\
\text { pre-service } \\
\text { teachers when } \\
\text { practicing their } \\
\text { micro-teaching } \\
\text { sessions }\end{array}$ & 14.0 & 12.0 & - & 55.0 & 19.0 & 2.47 & 1.31 & 1 & 5 & 1.72 \\
\hline 59 & $\begin{array}{l}\text { Separation of } \\
\text { theory from } \\
\text { practice can } \\
\text { help pre- } \\
\text { service } \\
\text { teachers to } \\
\text { learn from } \\
\text { observing their } \\
\text { peers. }\end{array}$ & 16.0 & 28.0 & - & 39.0 & 17.0 & 2.87 & 1.41 & 1 & 5 & 1.99 \\
\hline 60 & $\begin{array}{l}\text { Combination } \\
\text { of theory and } \\
\text { practice can } \\
\text { help pre- } \\
\text { service } \\
\text { teachers to } \\
\text { learn from } \\
\text { observing their } \\
\text { peers. }\end{array}$ & 12.0 & 21.0 & - & 47.0 & 20.0 & 2.58 & 1.34 & 1 & 5 & 1.80 \\
\hline 61 & $\begin{array}{l}\text { Separation of } \\
\text { theory from } \\
\text { practice can } \\
\text { help pre- } \\
\text { service } \\
\text { teachers in } \\
\text { their lesson } \\
\text { planning }\end{array}$ & 17.0 & 55.0 & - & 22. & 6.0 & 3.55 & 1.18 & 1 & 5 & 1.40 \\
\hline 62 & $\begin{array}{l}\text { Combination } \\
\text { of theory and } \\
\text { practice can } \\
\text { help pre- } \\
\text { service } \\
\text { teachers in } \\
\text { their lesson }\end{array}$ & 10.0 & 11.0 & - & 56.0 & 23.0 & 2.29 & 1.22 & 1 & 5 & 1.50 \\
\hline
\end{tabular}




\begin{tabular}{|c|c|c|c|c|c|c|c|c|c|c|c|}
\hline \multicolumn{7}{|c|}{ Dr. Marghany Mahmoud Marghany } & \multicolumn{5}{|c|}{ Dr. Mai Ahmed El-Said } \\
\hline No. & $\begin{array}{l}\text { Part 1: Items } \\
\text { of tools }\end{array}$ & $\begin{array}{l}\text { SD } \\
5 \%\end{array}$ & $\begin{array}{l}\mathrm{D} \\
4 \%\end{array}$ & $\begin{array}{l}\text { Not } \\
\text { Sure } \\
3\end{array}$ & $\begin{array}{l}\text { SA } \\
2 \\
\%\end{array}$ & A 1 & Mean & $\begin{array}{l}\text { St. } \\
\text { Dev. }\end{array}$ & Min & $\operatorname{Max}$ & variance \\
\hline & planning & & & & & & & & & & \\
\hline 63 & $\begin{array}{l}\text { Separation of } \\
\text { theory from } \\
\text { practice can } \\
\text { help pre- } \\
\text { service } \\
\text { teachers in } \\
\text { preparing their } \\
\text { lessons }\end{array}$ & 22.0 & 40.0 & 9.0 & 23.0 & 6.0 & 3.49 & 1.23 & 1 & 5 & 1.52 \\
\hline 64 & $\begin{array}{l}\text { Combination } \\
\text { of theory and } \\
\text { practice can } \\
\text { help pre- } \\
\text { service } \\
\text { teachers in } \\
\text { preparing their } \\
\text { lessons }\end{array}$ & 9.0 & 35.0 & - & 34.0 & 22.0 & 2.75 & 1.37 & 1 & 5 & 1.88 \\
\hline
\end{tabular}

Table 2 confirmed the participants' views on the mechanisms of conducting the microteaching course as $(73 \%)$ preferred online lectures to face-face lectures. Among different online means, the participants (38.46\%) preferred the Microsoft teams programme to follow up the microteaching course. Their preference was based on the facts that Microsoft teams provides better interaction opportunities with the course instructors compared to other programmes indicated in Tables 2. In addition, through the Microsoft teams, they can see the instructors' facial expressions which improve their understanding of the lecture's content. They also asserted that the Microsoft teams programme is a comprehensive programme that allows them do assignments and follow up their year works marks. As for the methods of conducting the microteaching course, Table 2 confirmed the preference of having theoretically-practically combined sessions rather than having separatelted sessions of theory and practice. They indicated that it is more effective to combine theoretical and practical aspects of the course within the same sessions rather than separating them in different sessions. This combination allows them to have immediate feedback whether from peers or instructors in order to improve their teaching performance. 
The impact of COVID-19 on the mechanisms and methods of conducting the microteaching course: The case of sophomore students at October 6 University

Table 2: Descriptive Statistics of the Interview Task

\begin{tabular}{|l|l|l|l|l|}
\hline Item & F & $\%$ & Mean Score & $\begin{array}{l}\text { Standard } \\
\text { Deviation }\end{array}$ \\
\hline $\begin{array}{l}\text { Face to face sessions } \\
\text { are better in } \\
\text { conducting } \\
\text { microteaching } \\
\text { sessions }\end{array}$ & 27 & 27 & 2.7 & 0.81 \\
\hline $\begin{array}{l}\text { Online lectures are } \\
\text { better in conducting } \\
\text { microteaching } \\
\text { sessions }\end{array}$ & 73 & 73 & 7.3 & 2.09 \\
\hline $\begin{array}{l}\text { Power point with } \\
\text { recorded voice }\end{array}$ & 5 & 7.79 & 1.17 & 1.01 \\
\hline $\begin{array}{l}\text { Multi Media Video } \\
\text { player }\end{array}$ & 15 & 23.07 & 4.28 & 3.21 \\
\hline Zoom Classes & 20 & 30.77 & 8.31 & 6.35 \\
\hline Microsoft Teams & 25 & 38.46 & 9.34 & 8.44 \\
\hline Separated sessions & 44 & 44 & 4.4 & 2.14 \\
\hline Combined sessions & 56 & 56 & 5.6 & 3.86 \\
\hline
\end{tabular}

\section{Teaching implications and conclusion}

The present study concluded that online learning is no longer an option; it is a must. The higher learning institutions in Egypt, including the October, 6 University, have to develop more advanced online platforms to face the prolonged effects of COVID-19 pandemic. Online teaching should be effective and interactive. It should encourage students' participation and interaction during the online courses. This will help reduce the feeling of being bored among students and will make such online courses as interesting as the face-to-face classes. To enhance the process of learning on the part of students, online courses should be based on creativity and should reinforce collaborative learning. Instructors should prepare effective strategies to give clear instructions to their students in a way that maximize their participation in the forms of having feedback from students, giving them opportunities to raise questions and widening the knowledge of the online course being taught.

As for the first question: which teaching mechanism do participants think is better for conducting the micro-teaching sessions, face-to-face lectures or online lectures? Why? October 6 University sophomores decided that online lectures are the best mechanism to study microteaching sessions in comparison to face-to-face lectures during the time of COVID19 pandemic. This finding is compatible with those reported by Besser, et al. (2020), and Dhawan (2020) and contradict the findings reported by Bao (2020) and Garris and Fleck (2020).This is evident in the higher 
percentages of strongly agree to part 1 items with the exception of two items only. In comparison to face-to-face lectures, the participants perceived that online lectures had privileges in conducting the microteaching sessions. These privileges include keeping social distance and reduction of socialization to lessen the probability of Corona Virus infection. Based on the participants' view, online lectures are better in describing their performance, fulfilling interaction with students, organizing the group work with students, handling the student's evaluation sheet, For sticking to a lesson timing schedule, determining the successful parts of their lesson, determining how successful was the lesson, describing any parts of their lesson that they were unhappy with, helping them think of lesson improvement, evaluating presentation of the lesson materials, and accurate planning of lessons and preparation of lesson.

As for the second question: what type of online lectures do they prefer? The present study concluded that the Microsoft teams programme is the best online programme for conducting the microteaching course at the faculty of Education, October 6 University. This is attributed to the privileges which the programme offers to the participants. It helps them to have better interaction with the instructors compared to other online programmes. It enables them to see the instructors' facial expressions which are necessary to improve their understanding of the lectures. It also facilitates their tasks of doing and submitting assignments. They can also follow their marks online through that programme.

As for the third question: which teaching method do participants think is better in conducting the micro-teaching sessions, separated sessions of theory and practice or combined sessions of theory and practice? Why? The majority of participants strongly agreed that combination of theory and practice sessions is the best method of conducting the microteaching sessions. They were against separating both theory and practice in attending these sessions. They perceived that the combined sessions of theory and practice have the same privileges like those of online lectures. They were of the opinions that it would be better to combine the practice of lesson planning, organization and assessment with the theory sessions. 
The impact of COVID-19 on the mechanisms and methods of conducting the microteaching course: The case of sophomore students at October 6 University

\section{Recommendations for further research}

The present study proposes the following recommendations for further research:

1. A study can investigate the impact of COVID-19 on the teaching of the four Language skills in the Egyptian context.

2. A study can be conducted to investigate how COVID-19 has affected the Egyptian EFL learners' motivation and attitude towards learning English.

3. A study may analyze the influence of COVID-19 on the development of soicopragmatic competence of the Egyptian EFL learners at different education levels.

4. A study can analyze the role of connectivism in helping the Egyptian EFL learners cope with the closure of learning institutions due to COVID-19.

5. A study can investigate the modification procedures which curricula planners have adopted to encounter COVID-19.

6. A study can assess the recommendations introduced to face the challenges of COVID-19 at the level of higher education. 


\section{References}

Arthur, J., \& Waring, M. (2017). Research methods and methodologies in education, $2^{\text {nd }}$ edition. Los Anglos: SAGE.

Bao, Wei, (2020). COVID-19 and online teaching in higher education: A case of study of Peking University. Human Behaviour \& Emergency Technology,2, 113-115. https://doi.org/10.1002/hbe2.191

Besser, A., Flett, G. L., and Zeigler-Hill, V. (2020). Adaptability to a sudden transition to online learning during the COVID-19 pandemic: understanding the challenges for students. Scholarship of Teaching and Learning in Psychology, pp. 1-21. http://dx.doi.org/10.1037/st10000198

Christensen, L. B., Johnson, R. B., \& Turner, L. A. (2014). Research methods, design, and analysis, twelfth edition. New Jersey: Pearson.

Cohen, L., Manion, L., \& Norrison, K. (2007). Research methods in education. New York: Routledge.

Dhawan, S. (2020). Online learning: A panacea in the time of COVID-19 crisis. Journal of Educational Technology Systems, Vol., 49, 1, pp. 5-22.

Garris.C. P., and Fleck, B. (2020). Student evaluation of the transitioned-online course during COVID-19 pandemic. Scholarship of Teaching and Learning in Psychology, pp.1-21 http://dx.doi.org/10.1037/st10000229

Hartawati,K. M., Sudirman, N. and Adnayni, L.D. (2018). Analysis of sixth semester students' perception toward microteaching in the context curriculum 2013 in English language education. International Journal of Language and Literature, Vol. 2, 4, pp. 169-177.

Johnson, R. B., \& Christensen, L. (2015). Educational Research: Quantitative, Qualitative, and Mixed Approaches (5th Ed.). South Alabama: SAGE Publication, Inc.

Leedy, P. D., \& Ormrod, J. E. (2013). Practical research: planning and design, tenth edition. New Jersey: Pearson.

Martin, D., \& Jamieson-Proctor, R. (2020). Development and validation of a survey instrument for measuring pre-service teachers' pedagogical content knowledge. International Journal of Research and Method in Education, Vol. 43,5, pp.512-525.

O'Neill, D. K. (2016). Understanding Design Research-Practice Partnerships in Context and Time: Why Learning Sciences Scholars Should Learn from Cultural-Historical Activity Theory Approaches to Design-Based Research. Journal of the Learning Sciences, 25(4), 497-502.

Pramodini, D. V., \& Anu Sophia, K. (2012). Evaluation for importance of research in education. International Journal of Social Science \& Interdisciplinary Research, Vol.1, 9, pp. 1-6.

Tight, M. (2018). Higher Education Research: The Developing Field. London: Bloomsbury Academic.

Williams, K. (2015). Doing Research To Improve Teaching and Learning. New York: Routledge. 
The impact of COVID-19 on the mechanisms and methods of conducting the microteaching course: The case of sophomore students at October 6 University

UNESCO. (2020, Match 13). COVID-19 educational disruption and response. Retrieved from https://en.unesco.org/themes/educationemergencies/coronavirus-school-closures 